Review

\title{
Impact of Autophagy of Innate Immune Cells on Inflammatory Bowel Disease
}

\author{
Tomoya Iida $\mathbb{D}$, Yoshihiro Yokoyama, Kohei Wagatsuma, Daisuke Hirayama and \\ Hiroshi Nakase *iD \\ Department of Gastroenterology and Hepatology, Sapporo Medical University School of Medicine, \\ Sapporo 060-8543, Japan; tomoya.iida.0306@gmail.com (T.I.); yoshi_yokoyamaa@yahoo.co.jp (Y.Y.); \\ waga_a05m@yahoo.co.jp (K.W.); hirarin95@yahoo.co.jp (D.H.) \\ * Correspondence: hiropynakase@gmail.com; Tel.: +81-11-611-2111
}

Received: 4 December 2018; Accepted: 18 December 2018; Published: 22 December 2018

check for updates

\begin{abstract}
Autophagy, an intracellular degradation mechanism, has many immunological functions and is a constitutive process necessary for maintaining cellular homeostasis and organ structure. One of the functions of autophagy is to control the innate immune response. Many studies conducted in recent years have revealed the contribution of autophagy to the innate immune response, and relationships between this process and various diseases have been reported. Inflammatory bowel disease is an intractable disorder with unknown etiology; however, immunological abnormalities in the intestines are known to be involved in the pathology of inflammatory bowel disease, as is dysfunction of autophagy. In Crohn's disease, many associations with autophagy-related genes, such as ATG16L1, IRGM, NOD2, and others, have been reported. Abnormalities in the ATG16L1 gene, in particular, have been reported to cause autophagic dysfunction, resulting in enhanced production of inflammatory cytokines by macrophages as well as abnormal function of Paneth cells, which are important in intestinal innate immunity. In this review, we provide an overview of the autophagy mechanism in innate immune cells in inflammatory bowel disease.
\end{abstract}

Keywords: autophagy; innate immunity; immune cell; inflammasome; Paneth cell; inflammatory bowel disease; Crohn's disease

\section{Introduction}

The gastrointestinal tract is continuously involved in regulating the gut flora, modulating immune responses to food antigens and other substances, and maintaining homeostasis. Inflammatory bowel disease (IBD) occurs when this homeostasis is disrupted. The innate immune response is indispensable for maintaining homeostasis, and abnormal innate immune activity is deeply involved in the pathogenesis of IBD; research in this field has made substantial advancements in recent years [1-3]. To date, more than 200 IBD disease susceptibility loci have been identified by genome wide association studies (GWASs) [4,5]. Within these 200 loci, based upon single nucleotide polymorphism frequencies in patients with IBD versus controls, are approximately 1500 potential associated genes [6,7]. Numerous molecules involved in producing innate immune responses are also included among these loci.

Cells closely involved in the innate immune response with respect to IBD include blood cells, macrophages, dendritic cells, Paneth cells, and goblet cells, which are also involved in the pathology of IBD [8-10]. These cells have been found to play important roles in the development of abnormalities, including maintaining homeostasis against stress at the cellular level and modulating autophagy.

In this review, we outline the mechanism of autophagy in innate immune cells in IBD. 


\section{Pathology and Pathogenesis of IBD}

IBD is a chronic inflammatory disease involving idiopathic inflammation, primarily in the gastrointestinal tract; when defined more specifically, this condition encompasses ulcerative colitis (UC) and Crohn's disease (CD). Both are characterized by onset at a young age and the number of affected patients has risen sharply in recent years in Europe, the United States of America, and Japan [11]. Genetic predisposition (innate and acquired immunity, cytokine, and racial difference) and environmental factors (meal, drug, smoking, and infection) are greatly involved in the onset of IBD, and intestinal immune abnormalities are caused by the involvement of the state of dysbiosis, which is believed to cause IBD [11-15] (Figure 1).

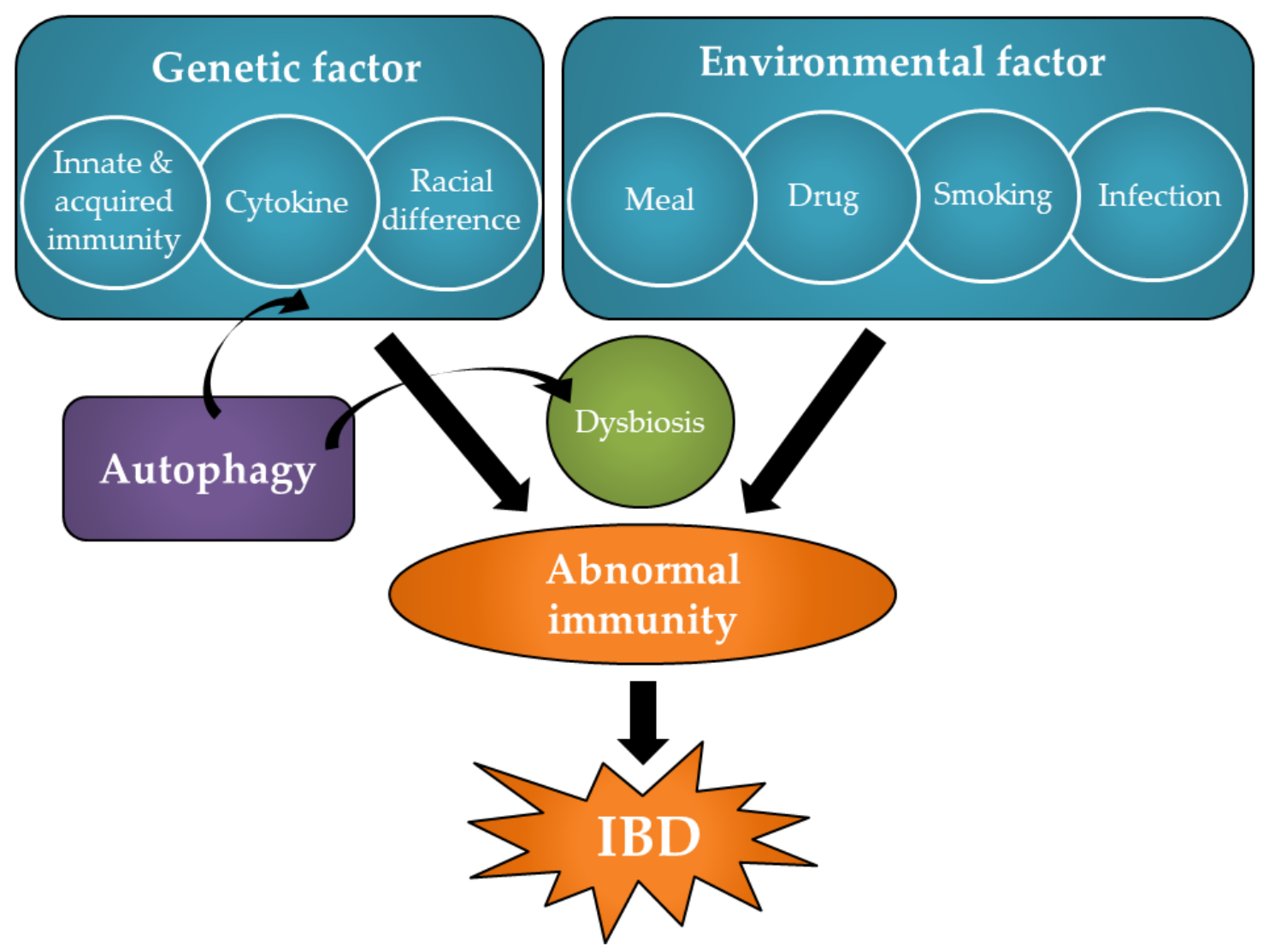

Figure 1. Pathology and pathogenesis of inflammatory bowel disease (IBD). Genetic predisposition and environmental factors are greatly involved in the onset of IBD, and intestinal immune abnormalities are caused by the involvement of the state of dysbiosis, which is believed to cause IBD.

Abnormalities related to genetic predisposition and autophagy are deeply involved in dysbiosis. Representative autophagy-related genes include nucleotide-binding oligomerization domain containing 2 (NOD2), autophagy-related 16 like 1 (ATG16L1), and immunity-related GTPase family M (IRGM) [16-18]. Autophagy has been linked to a variety of diseases; however, its link to IBD is currently the subject of much debate.

\section{Autophagy}

Autophagy is a term derived from a Greek word meaning "self-eating" and is a process that together with the ubiquitin-proteasome system, governs the degradation of intracellular proteins. In addition to immunological functions, such as antigen presentation and protection against infection, autophagy is also involved in the starvation response, carcinogenesis, and quality control of intracellular proteins and is a constitutive process necessary for maintaining proper cell homeostasis 
and organ health [19-21]. In addition to IBD, autophagy has been shown to be associated with other diseases, such as asthma [22-25], systemic lupus erythematosus [26,27], and Parkinson's disease [28,29].

During the autophagy process, the endoplasmic reticulum or other membranous cellular structures respond to stimuli by generating a double-membrane structure called a phagophore. The ATG16L1/ATG5/ATG12 complex multimerizes and then lipidates light chain 3 (LC3)-II on this phagophore. Concurrently, the phagophore elongates to envelop the cytoplasm or organelle to be degraded, forming an autophagosome, which is a unique double-membrane organelle. The outer membrane of the autophagosome then integrates with a lysosome and forms an autolysosome. Finally, the inner membrane degrades and absorbs its contents [30] (Figure 2).

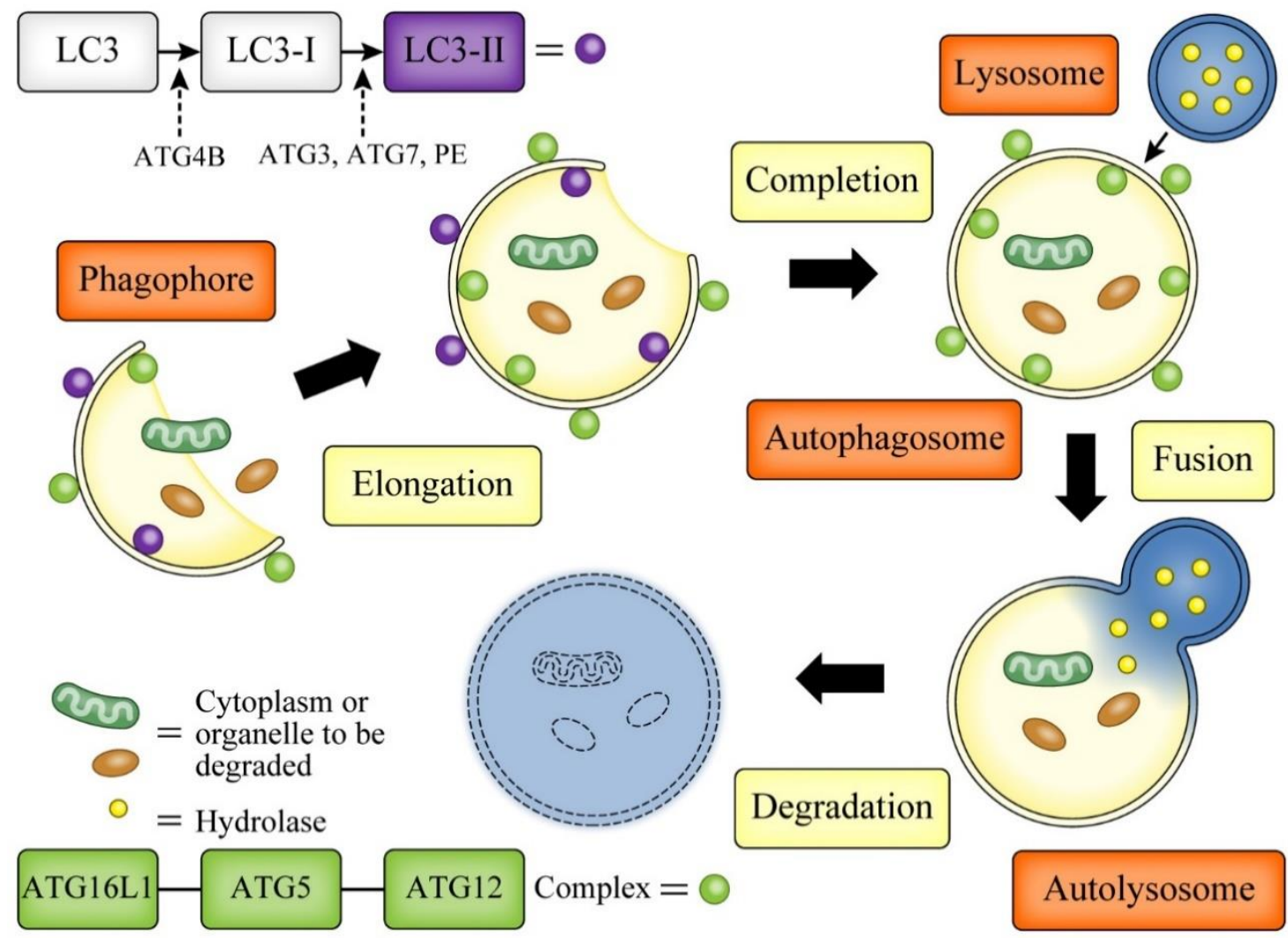

Figure 2. Autophagy mechanism. The endoplasmic reticulum or other membranous cellular structures respond to stimuli by generating a double-membrane structure called a phagophore. ATG16L1-ATG5-ATG12 complex multimerizes and then lipidates light chain 3 (LC3)-II on this phagophore. Concurrently, the phagophore elongates to envelop the cytoplasm or organelle to be degraded, forming an autophagosome. The outer membrane of the autophagosome then integrates with a lysosome and forms an autolysosome. Finally, the inner membrane degrades and absorbs its contents.

\section{Role of Autophagy in Innate Immunity}

One of the functions of autophagy is control of the innate immune response. Many studies have revealed the involvement of autophagy in innate immune reactions, and extremely precise control mechanisms and pathophysiological roles are becoming more clearly understood and have begun to be elucidated [31,32].

\subsection{Xenophagy, Mitophagy}

Innate immunity is a mechanism through which almost all multicellular organisms protect themselves from pathogens. This pathway is activated when the constructive patterns of pathogen's components are recognized (i.e., the cell wall components of a bacterial cell or the genome of a 
virus). Autophagy was initially thought to be a nonspecific mechanism for degrading substances by incorporating them into a membrane structure; however, recent studies have shown that autophagosomes selectively isolate a variety of substrates through sequestosome 1-like receptors, as is observed in autophagy of pathogens (xenophagy) [33-35]. Although the ubiquitin-proteasome system is a well-known selective intracellular degradation system, autophagy can selectively engulf and decompose small substances, such as mitochondria, which are larger than the targets of the ubiquitin-proteasome system, indicating characteristics similar to that of mitophagy [36,37]. The major difference between autophagosomes and other membranous organelles is that autophagosomes have a dynamic structure in which necessary fractions are newly created and disappear with the digestion of contents by fusion with lysosomes; as the necessity increases, as in the starvation state, its production efficiency dramatically increases. These features are convenient for quickly carrying out quantitative control, and even when functioning to control the immune response, autophagy is more suitable than degradation by the proteasome system, and it is believed to be essential for the resolution of quantitative problems. However, when autophagy works in connection with innate immunity, the substrates to be decomposed are rarely clear except in the cases of xenophagy and mitophagy.

\subsection{The Role of Autophagy in Inflammasomal and Type I Interferon Response}

A controllable receptor tripartite motif (TRIM) protein that facilitates autophagy by recruiting autophagy-regulating factors and recognizing the target of autophagy has recently been reported as a receptor for autophagy in a new process called precision autophagy [38]. Inflammasomal and type I interferon (IFN) responses are representative components of the precision autophagic processes involved in innate immunity.

The Nod-like receptor (NLR) family of proteins, including NLRP1, NLRP3, and NLRC4, together with the apoptosis-associated speck-like protein containing a caspase recruitment domain and the protease caspase-1, functions as downstream innate inflammasomes [39] that are activated in phagocytic cells, such as macrophages, and are induced by caspase- 1 via maturation of the inflammatory cytokines interleukin (IL)-1 $\beta$ and IL-18 and their subsequent production [40]. NLRP3 inflammasomes have attracted much attention in recent years with respect to various diseases [41-44], and numerous relationships between the state and severity of NLRP3 gene polymorphism and IBD presentation have also been reported [45-50].

The type I IFN response plays an essential role in the innate immune response to viral infection, and RNA derived from RNA viruses invading cells can be recognized by the helicase retinoic acid inducible gene $1 /$ melanoma differentiation-associated protein 5 and type I IFN [51]. Because signaling from type I IFN follows the Janus kinase/signal transducer and activator of transcription pathway, this cytokine has also been reported to be associated with IBD [52].

\subsubsection{Modulation of NLRP3 Inflammasome Suppression via Autophagy}

Gram-negative bacterial lipopolysaccharides (LPSs) stimulate toll-like receptor (TLR) 4 and induce the activation of NLRP3 inflammasomes in a TIR-domain-containing adapter-inducing IFN- $\beta$ (TRIF)-dependent manner with the information transfer factor. Active oxygen species derived from mitochondria are involved in the activation of NLRP3 inflammasomes. In the TRIF downstream pathway, evolutionarily conserved signaling intermediate in the Toll pathway has been reported as a factor that induces the production of reactive oxygen species (ROS) from mitochondria. This pathway is only slightly activated in wild-type macrophages. In addition, when phagolysosomes are damaged during gram-negative bacterial infection and LPS leaks into cells, NLRP3 inflammasomes are activated via a noncanonical pathway. Activation of the noncanonical pathway is thought to be induced by an unknown LPS sensor present in the cell. In addition, metabolites, such as urate crystals, cholesterol crystals, and free fatty acids, cause damage to phagolysosomes when taken up by macrophages, causing further mitochondrial damage. Adenosine triphosphate, which is known to activate surrounding cells after being released from dead cells, induces mitochondrial damage 
via the Purinergic $2 X 7$ receptor (P2X7R). Influenza viral infection can cause damage to organelles, such as mitochondria and the Golgi apparatus. When damaged mitochondria produce ROS, NLRP3 inflammasomes become activated. By suppressing this series of pathways, autophagy suppresses the activation of excessive inflammasomes [53-56] (Figure 3).

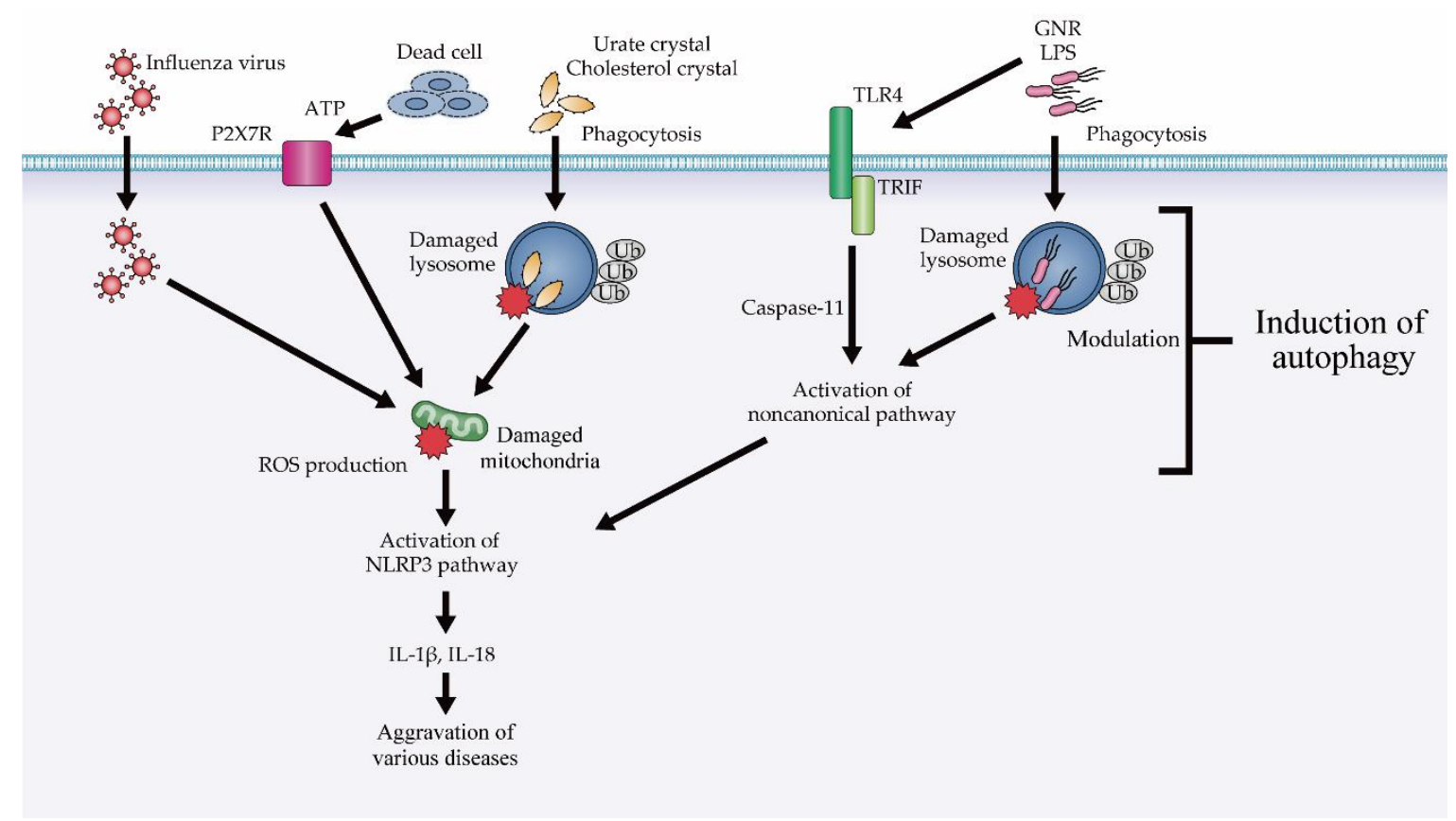

Figure 3. Modulation of NLRP3 inflammasome suppression via autophagy, ATP; adenosine triphosphate, GNR; gram negative rods, IL; interleukin, LPS; lipopolysaccharide, P2X7R; Purinergic $2 X 7$ receptor, ROS; reactive oxygen species, TLR4; Toll-like receptor 4, TRIF; TIR-domain-containing adapter-inducing interferon- $\beta, \mathrm{Ub}$; ubiquitin.

Autophagy is also believed to cause the decomposition of NLRP3 and AIM2, which are constituent factors of inflammasomes [57,58], and pro-IL-1 $\beta$ has been reported to be degraded by autophagy [59]. Furthermore, as described above, precision autophagy via TRIM protein is also involved in the decomposition of this inflammasome constituent factor by autophagy. TRIM20 binds to NLRP3 and pro-caspase 1, recruits autophagic regulatory factors (e.g., ULK1 and Beclin1), and is degraded by autophagy $[38,60,61]$.

Conversely, autophagy also positively regulates NLRP3 inflammasomes and is involved in both decomposition and secretion. Autophagy is involved in the secretion of cytokines, such as IL-1 $\beta$, IL-18, and high mobility group box 1 protein, and when inflammasomes become activated [62], folding of IL- $1 \beta$ by heat shock protein 90 is necessary; the IL- $1 \beta$ is then secreted after being transported to the lumen of LC3-II-positive autophagy-related structures [63].

Thus, autophagy plays an important role in the innate immune response by controlling NLRP3 inflammasomes. both positively and negatively.

\subsubsection{Modulation of Type I IFN Responses via Autophagy}

The TRIM protein regulates type I IFN responses via precision autophagy. TRIM21 binds to the IRF3 dimer, recruits autophagic regulators (e.g., ULK1 and Beclin1), and suppresses type I IFN responses by degrading this dimer via autophagy [61]. Moreover, autophagy also positively controls type I IFN responses. Intracellular viral replication intermediates on endosomes are recognized by TLR7 and cause a type I IFN response, but autophagy promotes type I IFN responses by this TLR7 via viral recognition [64]. As such, autophagy also positively and negatively controls type I IFN responses. 


\section{Role of Autophagy of Innate Immune Cells in IBD}

As discussed above, autophagic abnormalities are deeply involved in the pathology of IBD, particularly CD. Recently, GWASs identified several genetic variants, including variants of NOD2 [53,65-68], ATG16L1 [69-77], IRGM [78-81], and XIAP [82-87] linked to the onset of CD. NOD2 is the first disease-susceptibility gene discovered for CD [16]. Abnormalities in the NOD2 gene are found primarily in Westerners and not in Asians. NOD2 is an intracytoplasmic pattern recognition receptor belonging to the NLR family, which recognizes and defends against pathogens and foreign components invading the cytoplasm [88]. NOD2 is strongly expressed by macrophages and dendritic cells (DCs), particularly Paneth cells, and functions through mechanisms involving autophagy, intracellular bacterial sensing, modulation of the antibacterial peptide $\alpha$-defensin in the Paneth cells of the small intestine, and improvement of immune tolerance by suppressing TLR signals [89]. ATG16L1 is a homolog of ATG16, the existence of which was first reported by Mizushima et al. [69,70]. The ATG16L1 gene is involved in host immune responses against intracellular parasitic bacteria and viruses via autophagy. In particular, the ATG16L1 gene is closely associated with Paneth cells and plays an important role in $C D$ pathology. In addition, many genes are associated with various pathologies of IBD in connection with autophagy, and these genes play important roles in immune cells, such as macrophages and DCs, as well as intestinal epithelial cells, including Paneth cells. The relationship between immune cells and autophagy in the IBD state is described below.

\subsection{Hematopoietic Cells}

\subsubsection{Macrophages and DCs}

Macrophages and DCs phagocytose foreign substances and bacteria in different tissues, serve as a first line of defense, and act as antigen-presenting cells to exert the functions of the acquired immune system $[90,91]$. Given the key role of the interactions between host and microbes in the intestine, it is critical to properly regulate pattern recognition receptor (PRR) signals and cytokine secretion. The NLRs in the cytoplasm and TLRs on the cell surface are the two main types of PRRs in innate immune cells [92]. NLRs and TLRs in macrophages are closely associated with autophagy, and macrophage autophagy is highly related to the mediation of innate immune responses in the intestinal wall $[16,17]$. Additionally, various antigens are degraded by the actions of proteasomes and lysosomes and are then presented by macrophages and DCs via class I and class II MHCs, after which the adaptive immune system is activated. Although it remains unclear as to how intracellular antigens are delivered to lysosomes and decomposed, recent studies have shown that autophagy is deeply involved in this process [93]. In the following section, we describe the relationships among macrophages, DCs, and autophagy in the pathology of IBD with respect to three components: pathogen degradation, suppression of inflammatory cytokine secretion, and antigen presentation.

\section{Pathogen Degradation}

NOD2 recruits the autophagy protein ATG16L1 to the plasma membrane at the bacterial entry site; mutant NOD2 fails to recruit ATG16L1 to the plasma membrane, and the wrapping of invading bacteria by the autophagosome is impaired. Thus, patients with CD with NOD2 variants exhibit autophagy-related disorders [65-68]. Additionally, the capacity for autophagy and the phagocytosis of pathogenic bacteria become impaired in macrophages harboring mutant NOD2 [94]. Furthermore, autophagy has been reported to be impaired in macrophages transfected with siRNA targeted to ATG16L1 or IRGM, and intracellular adherent-invasive Escherichia coli (AIEC) populations increase in the presence of intraperitoneal macrophages in NOD2-deficient mice [95]. Moreover, death-receptor activation or starvation-induced metabolic stress in human and murine macrophages increases the degradation of T300A or T316A variants of ATG16L1, respectively, resulting in diminished autophagy. In addition, knock-in mice harboring the ATG16L1 T316A variant show defective clearance of the ileal pathogen Yersinia enterocolitica [74]. In an experiment using a cell line originating from macrophages, 
infection with CD-associated AIEC or administration of LPS or muramyl dipeptide induces IRGM expression [81]. Macrophages and epithelial cells lacking GPR65 exhibit impaired autophagy for clearance of intracellular bacteria [96].

Suppressing Inflammatory Cytokine Secretion

ATG16L1-deficient macrophages are known to overproduce the inflammatory cytokine IL-1 $\beta$ in response to LPS stimulation, and the importance of ATG16L1 in inflammation has been described based on the finding that intestinal inflammation, induced by dextran sodium sulfate (DSS) intake in bone marrow chimeric mice, results in IL-1 $\beta$ overproduction by hematopoietic cells, leading to increased inflammation and cell fragility [53]. Moreover, in macrophages and DCs, autophagy controls IL-1 $\beta$ secretion by mediating the degradation of pro-IL-1 $\beta$ [59]. Furthermore, macrophages lacking ATG7, another autophagy-related factor, and macrophages that inhibit the activity of Vps34, which is essential for the induction of autophagy, also produce excessive quantities of IL- $1 \beta$ in response to LPS. Macrophages lacking ATG5 have also been reported to produce IL-1 $\beta$ in excess in response to the presence of gram-negative bacteria [97]. These phenomena are caused by the activation of NLRP3 inflammasomes due to autophagic disorders, and in recent years, activation of NLRP3 inflammasomes in response to various stimuli has been found to be controlled by autophagy [54-56] (Figure 3). In another recent report, impairing autophagy using ATG5 siRNA or an autophagy inhibitor (3-MA) was found to induce more robust initiation and activation of the NLRP3 inflammasome combined with increased caspase- 1 activation and IL- $1 \beta$ production in peritoneal macrophages treated with LPS/DSS. 3-MA has also been shown to aggravate symptoms of DSS-induced colitis [98].

Loss of the autophagy-related gene ATG16L1 has been shown to promote accumulation of the adaptor TRIF and enhance production of IFN- $\beta$ and IL- $1 \beta$ as downstream signaling molecules in macrophages [99]. Macrophages from IBD risk carriers show increased myotubularin-related protein 3 expression and, in turn, decreased autophagy and increased cytokine secretion [100]. DSS and Saccharomyces cerevisiae were also inoculated into mice deficient in ATG16L1, an autophagy-related gene specific to CD11c+ DCs. Colitis has been reported to be exacerbated by elevated levels of IL-1 $\beta$ and tumor necrosis factor (TNF)- $\alpha$ when exposed to Salmonella typhimurium [101].

\section{Antigen Presentation}

In DCs, autophagy controls how antigens are processed and presented for antigen presentation [93]. Both NOD2 1007fs and ATG16L1 T300A block muramyl dipeptide induction of autophagy, and this process is associated with defective bacterial handling in DCs and impaired antigen presentation in association with MHC class II at the cell surface [65]. Deletion of ATG16L1 in a mouse model resulted in increased T-cell stimulation by DCs [102]. Additionally, ATG7-deficient mouse DCs are unable to stimulate CD4+ T-cell activation when exposed to Toxoplasma gondii antigens [103].

\subsubsection{Neutrophils}

Neutrophils have strong phagocytic and bacterial killing ability against foreign materials and bacteria, similar to macrophages, and play a central role in innate immunity [104]. Neutrophils react sensitively to stimuli and exhibit various functions. The initial response of neutrophils is quick, and neutrophils are subjected to sophisticated control mechanisms because they are involved in tissue restoration and minimization of injury to surrounding tissues. When this balance is impaired, neutrophils exhibit abnormal activation and are involved in various diseases [105]. Neutrophils are also involved in IBD pathophysiology and have been reported to be associated with cytokines, chemokines, ROS, and elastase [106]. Several reports have described the relationship between neutrophils and autophagy in IBD. For example, impaired Salmonella typhimurium clearance and increased ROS production were observed in ATG16L1-deficient murine neutrophils [107]. Thus, autophagy-related ATG16L1 is essential for bacterial clearance and suppression of ROS production by neutrophils. In addition, autophagy receptor optineurin-deficient mice have been shown to be more susceptible to 
Citrobacter colitis and E. coli peritonitis and showed reduced levels of TNF- $\alpha$ in serum and diminished neutrophil recruitment to sites of acute inflammation compared with that in wild-type mice [108]. Thus, the autophagy receptor optineurin plays a role in acute inflammation and neutrophil recruitment.

\subsubsection{Innate Lymphoid Cells (ILCs)}

ILCs are innate immunocompetent cells belonging to the lymphocyte system; some are similar to helper T cells, although cytotoxic natural killer cells (NKs) are also considered ILCs. ILCs are classified into groups 1-3 based on cytokine production. Group I ILCs include ILC1s and NK cells, ILC2s are assigned to group 2 ILCs, and group 3 ILCs include ILC3s. These groups of cells have attracted much attention from researchers interested in IBD pathology and are important for the maintenance of homeostasis and inflammatory immune responses [109]. In addition, autophagy has been shown to be required for ILC development and function. Atg5, an essential component of the autophagy machinery, is required for the development of mature NKs and group 1-3 ILCs [110]. Phosphorylated Forkhead box O (FoxO) 1 is localized in the cytoplasm of immature NKs and interacts with ATG7. FoxO1-mediated autophagy has been shown to be required for NK development and NK-induced innate immunity [111,112].

\subsubsection{NKT Cells (NKTs)}

NKTs are immunocompetent cells that recognize antigens presented mainly on CDld molecules of antigen-presenting cells and produce cytokines. Because CD1d-restricted NKTs have an invariant T-cell receptor $\alpha$ chain, these cells are expressed as intramucosal NKTs (iNKTs). Mice with oxazolone-induced enteritis are considered a Th2-dominant ulcerative colitis model, and IL-13 produced from iNKTs is an associated cytokine [113]. It has been reported that the number of NKTs is increased in the intestinal mucosa of patients with ulcerative colitis, and IL-13 production is enhanced [114]. Thus, NKTs are thought to be involved in the pathogenesis of IBD, and autophagy is important for the development and differentiation of iNKTs $[115,116]$. Recent reports have demonstrated that IL-15 induces autophagy of NKTs via TBK-binding protein 1 [117].

\subsection{Intestinal Epithelial Cells}

\subsubsection{Paneth Cells}

Paneth cells are found at the base of small intestinal crypts and were first reported in 1888 as epithelial cells with dense coarse granules. Subsequently, $\alpha$-defensin, an antimicrobial peptide and an innate immune effector, was discovered within Paneth cell granules [118]. Paneth cells play an important role as intestinal epithelial cells responsible for innate immunity [119-121]. In Caucasians, abnormalities in the NOD2 gene, which was first identified as a CD susceptibility gene, inhibit $\alpha$-defensin secretion by Paneth cells $[122,123]$. In addition, in mice with low ATG16L1 expression, significant abnormalities were observed in the secretory pathway of Paneth cell granules, and in patients with CD harboring homozygous ATG16L1 T300A mutations, abnormal Paneth cells, similar to low ATG16L1 expression mice, were reported to have been found in noninflammatory sites in the ileum [72]. In addition, as described above, autophagic abnormalities are involved in the pathology of $\mathrm{CD}$, and abnormal control of endoplasmic reticulum stress (ERS), ROS, and gut flora by Paneth cells each play important roles.

ER Stress (ERS)

Various intracellular proteins are synthesized in the ER, and these proteins undergo proper folding and are transported to the Golgi apparatus. Unfolded or misfolded proteins accumulate in the ER. The accumulation of proteins with these conformational abnormalities is called ERS, and excessive ERS ultimately induces cell apoptosis. The homeostatic mechanism mediating excessive ERS is known as the unfolded protein response (UPR). The UPR plays an important role in the survival and function of 
intestinal epithelial cells. In recent studies, the UPR has been shown to control abnormalities involved in the pathogenesis of IBD, and several genes associated with ERS have been reported as disease susceptibility genes by GWASs $[12,13,21,89]$.

As intestinal epithelial cells, Paneth cells are closely related to ERS [12]. ERS results in the induction of autophagy in Paneth cells through three signaling pathways: insulin response element (IRE) 1/c-Jun N-terminal kinase/nuclear factor-kB/X-box binding protein 1 (XBP-1), pancreatic ER kinase/eukaryotic initiation factor (eIF) $2 \alpha$-activated transcription factor 4 , and GRP78-activated transcription factor 6/CCAAT-enhancer-binding protein homologous protein signaling pathways [124-126]. In terms of genetic abnormalities, reports describing the relationships between ERS and autophagy in Paneth cells have focused on the roles of the NOD2 and ATG16L1 genes [12,122,127-129]. Secretory autophagy, which is triggered in Paneth cells by bacteria-induced ERS and limited bacterial dissemination, is disrupted in Paneth cells expressing ATG16L1 T300A [122]. In mice lacking ATG16L1 specifically in the epithelium, CD-like ileitis occurs spontaneously in an age-dependent manner in Paneth cells, which are ERS sensors and causes changes in IRE1 $\alpha$, which is important for Paneth cell homeostasis [129]. ER stress is induced via deletion of the UPR transcription factor XBP-1 in the intestinal epithelium, resulting in autophagosome formation in Paneth cells via a mechanism involving the eukaryotic translation initiation factor eIF2 $\alpha$ [8]. Thus, the involvement of autophagy in ERS may be a new therapeutic target for IBD in the future.

\section{ROS}

ROS have been shown to be involved in the pathogenesis of IBD, and many reports have suggested that IBD is associated with an imbalance between ROS and antioxidant activity, causing oxidative stress as a result of either ROS overproduction or decreased antioxidant activity [130-132]. Although many of the details of the relationship between ROS and autophagy have not been elucidated, accumulation of ROS has been reported to be related to induction of autophagy [133]. Notably, mitochondrial dysfunction is known to trigger the accumulation of ROS in Paneth cells, resulting in induction of autophagy through the p53/TP53 induced glycolysis regulatory phosphatase/damage-regulated autophagy modulator, p62-NF-E2-related factor 2, and BCL2/adenovirus E1B $19 \mathrm{kDa}$ protein-interacting protein 3 pathways, thus protecting against cellular damage caused by various stresses [134,135]. Additionally, mutations in Atg promote the production of ROS via mitochondrial insufficiency in Paneth cells [136]. Further studies are needed to fully elucidate the relationship between ROS and autophagy in IBD.

\section{Gut Microbiota}

There are in the order of 100 trillion intestinal bacteria present in the human intestinal tract, and these cells play important roles in maintaining host metabolism and immunological homeostasis. Although findings suggesting the involvement of intestinal bacteria in the pathology of IBD are accumulating, it is unclear whether changes in the composition of the gut flora are the cause of IBD. Paneth cells are important factors influencing the gut flora [137], and autophagy abnormalities in Paneth cells are known to be related to alterations in the gut flora [137-139]. Autophagy dysfunction in Paneth cell disrupts the normal intestinal flora and promotes intracellular survival of AIEC and Salmonella typhimurium [138]. Vitamin D receptors in the intestinal tract contribute to Paneth cell function, autophagy function, and maintenance of normal intestinal microflora via ATG16L1 [139]. In addition, the microbiota induces basal Paneth cell autophagy by IFN- $\gamma$, facilitating the maintenance of intestinal homeostasis [140]. Dysfunction of autophagy by Paneth cells has also been reported to cause not only changes in the gut microbiome, but also improper responses to the altered flora [141]. As described above, the gut flora is closely related to autophagic abnormalities in Paneth cells, and many IBD treatments, particularly those utilizing probiotics, aim to correct intestinal bacterial flora populations $[142,143]$. 


\subsubsection{Goblet Cells}

Goblet cells are intestinal epithelial cells with cytoplasmic granules containing large quantities of mucin, a glycoprotein [144,145]. In the gastrointestinal tract, Goblet cells can be found in both the small intestine and the large intestine, and mucin secreted into the intestinal lumen is thought to contribute to mucosal protection and repair of the intestinal epithelium [146]. Dysfunction in mucin secretion and defects in the mucus layer allow large quantities of bacteria to reach the epithelium and trigger excess host immune responses, which have been shown to be associated with IBD [147].

In recent studies, autophagy has been reported to affect the functions of Goblet cells. Mice or cells lacking autophagy by depletion of autophagy-related proteins, such as ATG5, ATG7, ATG16L1, and LC3, show altered goblet cell morphology and decreased mucin secretion $[73,148,149]$. In addition, inflammasomes have been shown to be involved in mucin secretion by Goblet cells, and NLRP6 inflammasomes have been reported to promote excocytosis of mucin by Goblet cells through promotion of autophagy [150]. Sonic hedgehog intestinal epithelial conditional knockout mice showed decreased numbers of ileal mucin-secreting Goblet cells accompanied by a significant reduction in autophagy [151]. Apple polysaccharide has been shown to inhibit dysbiosis-associated gut permeability and chronic inflammation due to the induction of autophagy in Goblet cells [152]. As described above, Goblet cells play important roles in the secretion of mucin via autophagy, act to maintain intestinal microflora, and are attracting attention as new therapeutic targets for IBD $[149,153,154]$.

An overview of the autophagy mechanism of innate immunity cells in IBD is shown in Figure 4.

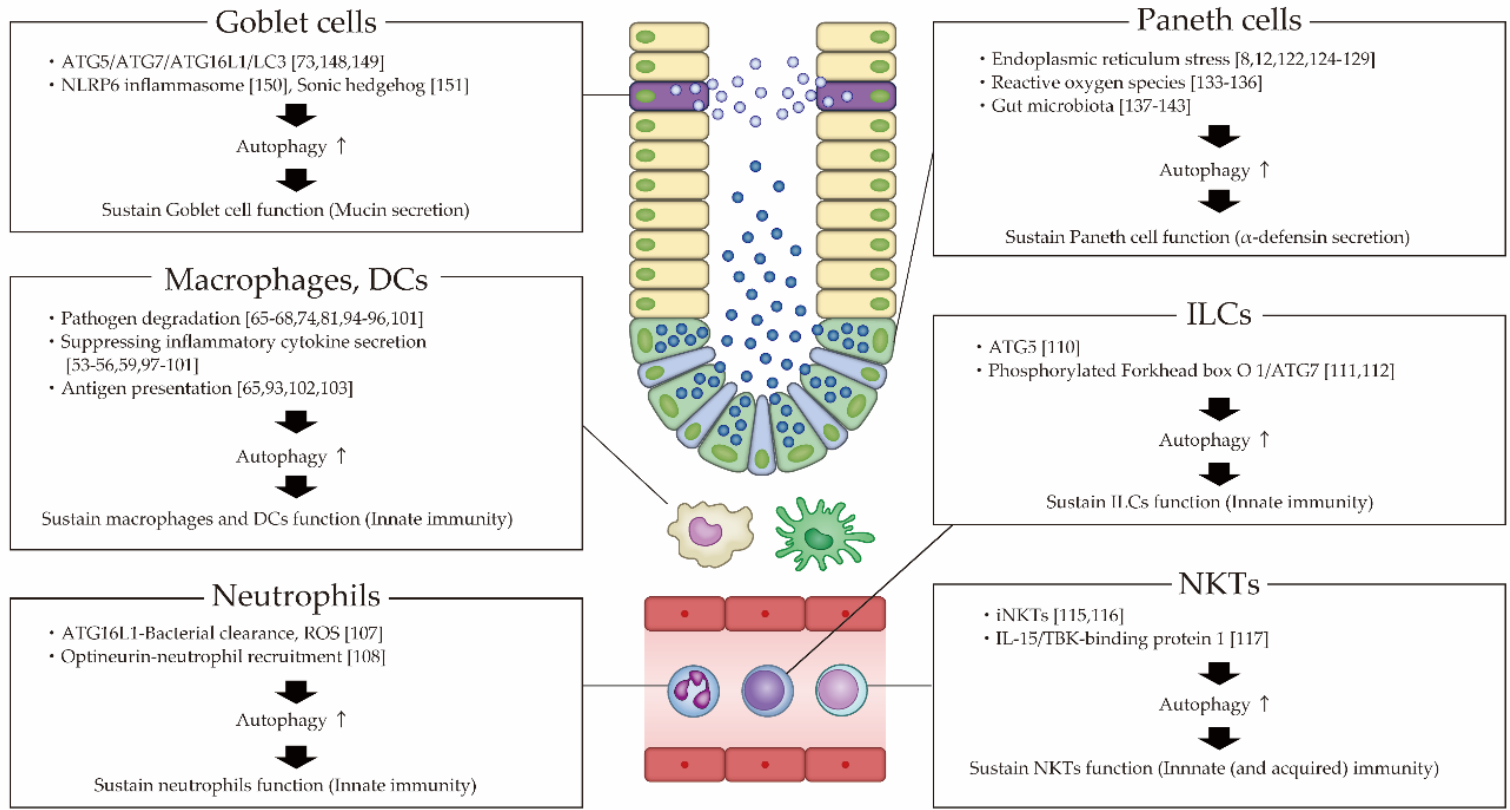

Figure 4. Role of autophagy of innate immune cells on IBD. DCs; dendritic cells, IL; interleukin, ILCs; innate lymphoid cells, NKTs; natural killer T cells, ROS; reactive oxygen species.

\section{Conclusions}

In this review, we have provided an overview of the autophagy mechanism of innate immune cells in IBD. Numerous studies have revealed that autophagy is an essential key player in controlling inflammatory responses mediated by innate immune cells. We anticipate that in the future, and based on further research, a therapy based on autophagic control will be established for IBD, a condition that does not yet have a curative therapy. 
Author Contributions: Conceptualization, T.I. and H.N.; Investigation, T.I., Y.Y., K.W. and D.H.; Writing-Original Draft Preparation, T.I., Y.Y., K.W. and D.H.; Writing-Review \& Editing, H.N.; Supervision, H.N.; Funding Acquisition, T.I. and H.N.

Funding: This work was partly supported by Health and Labour Sciences Research Grants for research on intractable diseases from the Ministry of Health, Labour and Welfare of Japan (Investigation and Research for intractable Inflammatory Bowel Disease), and Japan Society for the Promotion of Science (JSPS) Grants-in-Aid for Scientific Research (KAKENHI) Grant Number JP17J02428 (to T.I.) and JP18H02799 (to H.N.). The funders of the study had no role in the study design, data collection, data analysis, data interpretation, or writing of the report.

Conflicts of Interest: The authors have nothing to declare.

\section{References}

1. Ebbo, M.; Crinier, A.; Vély, F.; Vivier, E. Innate lymphoid cells: Major players in inflammatory diseases. Nat. Rev. Immunol. 2017, 17, 665-678. [CrossRef] [PubMed]

2. Choy, M.C.; Visvanathan, K.; De Cruz, P. An overview of the innate and adaptive immune system in inflammatory bowel disease. Inflamm. Bowel Dis. 2017, 23, 2-13. [CrossRef] [PubMed]

3. Lee, S.H.; Kwon, J.E.; Cho, M.L. Immunological pathogenesis of inflammatory bowel disease. Intest. Res. 2018, 16, 26-42. [CrossRef] [PubMed]

4. Jostins, L.M.; Ripke, S.; Weersma, R.K.; Duerr, R.H.; McGovern, D.P.; Hui, K.Y.; Lee, J.C.; Schumm, L.P.; Sharma, Y.; Anderson, C.A.; et al. Host-microbe interactions have shaped the genetic architecture of inflammatory bowel disease. Nature 2012, 491, 119-124. [CrossRef] [PubMed]

5. Liu, J.Z.; van Sommeren, S.; Huang, H.; Ng, S.C.; Alberts, R.; Takahashi, A.; Ripke, S.; Lee, J.C.; Jostins, L.; Shah, T.; et al. Association analyses identify 38 susceptibility loci for IBD and highlight shared genetic risk across populations. Nat. Genet. 2015, 47, 979-986. [CrossRef] [PubMed]

6. Cho, J.H.; Brant, S.R. Recent insights into the genetics of inflammatory bowel disease. Gastroenterology 2011, 140, 1704-1712. [CrossRef] [PubMed]

7. Ek, W.E.; D'Amato, M.; Halfvarson, J. The history of genetics in inflammatory bowel disease. Ann. Gastroenterol. 2014, 27, 294-303. [PubMed]

8. Adolph, T.E.; Tomczak, M.F.; Niederreiter, L.; Ko, H.J.; Böck, J.; Martinez-Naves, E.; Glickman, J.N.; Tschurtschenthaler, M.; Hartwig, J.; Hosomi, S.; et al. Paneth cells as a site of origin for intestinal inflammation. Nature 2013, 503, 272-276. [CrossRef] [PubMed]

9. Patman, G. Crohn's disease. TCF1 regulates Paneth cell $\alpha$-defensins. Nat. Rev. Gastroenterol. Hepatol. 2014, 11,517. [CrossRef]

10. Eriguchi, Y.; Nakamura, K.; Yokoi, Y.; Sugimoto, R.; Takahashi, S.; Hashimoto, D.; Teshima, T.; Ayabe, T.; Selsted, M.E.; Ouellette, A.J. Essential role of IFN- $\gamma$ in T cell-associated intestinal inflammation. JCI. Insight. 2018, 20, pii:121886. [CrossRef]

11. Molodecky, N.A.; Soon, I.S.; Rabi, D.M.; Ghali, W.A.; Ferris, M.; Chernoff, G.; Benchimol, E.I.; Panaccione, R.; Ghosh, S.; Barkema, H.W.; et al. Increasing incidence and prevalence of the inflammatory bowel diseases with time, based on systematic review. Gastroenterology 2012, 142, 46-54. [CrossRef] [PubMed]

12. Kaser, A.; Blumberg, R.S. Autophagy, microbial sensing, endoplasmic reticulum stress, and epithelial function in inflammatory bowel disease. Gastroenterology 2011, 140, 1738-1747. [CrossRef] [PubMed]

13. Kaser, A.; Zeissig, S.; Blumberg, R.S. Inflammatory bowel disease. Annu. Rev. Immunol. 2010, $28,573-621$. [CrossRef] [PubMed]

14. Khor, B.; Gardet, A.; Xavier, R.J. Genetics and pathogenesis of inflammatory bowel disease. Nature 2011, 474, 307-317. [CrossRef]

15. Weterman, I.T.; Peña, A.S. Familial incidence of Crohn's disease in the Netherlands and a review of the literature. Gastroenterology 1984, 86, 449-452.

16. Hugot, J.P.; Chamaillard, M.; Zouali, H.; Lesage, S.; Cézard, J.P.; Belaiche, J.; Almer, S.; Tysk, C.; O'Morain, C.A.; Gassull, M.; et al. Association of NOD2 leucine-rich repeat variants with susceptibility to Crohn's disease. Nature 2001, 411, 599-603. [CrossRef]

17. Ogura, Y.; Bonen, D.K.; Inohara, N.; Nicolae, D.L.; Chen, F.F.; Ramos, R.; Britton, H.; Moran, T.; Karaliuskas, R.; Duerr, R.H.; et al. A frameshift mutation in NOD2 associated with susceptibility to Crohn's disease. Nature 2001, 411, 603-606. [CrossRef]

18. Goldstein, D.B. Common genetic variation and human traits. N. Engl. J. Med. 2009, 360, 1696-1698. [CrossRef] 
19. Levine, B.; Mizushima, N.; Virgin, H.W. Autophagy in immunity and inflammation. Nature 2011, 469, 323-325. [CrossRef]

20. Hooper, K.M.; Barlow, P.G.; Stevens, C.; Henderson, P. Inflammatory bowel disease drugs: A focus on autophagy. J. Crohn's Colitis 2017, 11, 118-127. [CrossRef]

21. Lassen, K.G.; Xavier, R.J. Mechanisms and function of autophagy in intestinal disease. Autophagy 2018, 14, 216-220. [CrossRef] [PubMed]

22. Zeki, A.A.; Yeganeh, B.; Kenyon, N.J.; Post, M.; Ghavami, S. Autophagy in airway diseases: A new frontier in human asthma? Allergy 2016, 71, 5-14. [CrossRef] [PubMed]

23. Poon, A.H.; Choy, D.F.; Chouiali, F.; Ramakrishnan, R.K.; Mahboub, B.; Audusseau, S.; Mogas, A.; Harris, J.M.; Arron, J.R.; Laprise, C.; et al. Increased autophagy-related 5 gene expression is associated with collagen expression in the airways of refractory asthmatics. Front. Immunol. 2017, 8, 355. [CrossRef] [PubMed]

24. Mabalirajan, U. A possible differential role of autophagy in asthma? J. Allergy Clin. Immunol. 2017, $139,712$. [CrossRef] [PubMed]

25. Racanelli, A.C.; Kikkers, S.A.; Choi, A.M.K.; Cloonan, S.M. Autophagy and inflammation in chronic respiratory disease. Autophagy 2018, 14, 221-232. [CrossRef] [PubMed]

26. Allison, S.J. Systemic lupus erythematosus: Defective noncanonical autophagy in SLE-like disease. Nat. Rev. Rheumatol. 2016, 12, 311. [CrossRef] [PubMed]

27. Mistry, P.; Kaplan, M.J. Cell death in the pathogenesis of systemic lupus erythematosus and lupus nephritis. Clin. Immunol. 2017, 185, 59-73. [CrossRef]

28. Fujikake, N.; Shin, M.; Shimizu, S. Association between autophagy and neurodegenerative diseases. Front. Neurosci. 2018, 12, 255. [CrossRef]

29. Harper, J.W.; Ordureau, A.; Heo, J.M. Building and decoding ubiquitin chains for mitophagy. Nat. Rev. Mol. Cell Biol. 2018, 19, 93-108. [CrossRef]

30. Iida, T.; Onodera, K.; Nakase, H. Role of autophagy in the pathogenesis of inflammatory bowel disease. World J. Gastroenterol. 2017, 23, 1944-1953. [CrossRef]

31. Rogov, V.; Dötsch, V.; Johansen, T.; Kirkin, V. Interactions between autophagy receptors and ubiquitin-like proteins form the molecular basis for selective autophagy. Mol. Cell 2014, 53, 167-178. [CrossRef] [PubMed]

32. Kawai, T.; Akira, S. The role of pattern-recognition receptors in innate immunity: Update on Toll-like receptors. Nat. Immunol. 2010, 11, 373-384. [CrossRef] [PubMed]

33. Mizushima, N.; Yoshimori, T.; Ohsumi, Y. The role of Atg proteins in autophagosome formation. Annu. Rev. Cell Dev. Biol. 2011, 27, 107-132. [CrossRef] [PubMed]

34. Levine, B. Eating oneself and uninvited guests: Autophagy-related pathways in cellular defense. Cell 2005, 120, 159-162. [CrossRef] [PubMed]

35. Nozawa, T.; Minowa-Nozawa, A.; Aikawa, C.; Nakagawa, I. The STX6-VTI1B-VAMP3 complex facilitates xenophagy by regulating the fusion between recycling endosomes and autophagosomes. Autophagy 2017, 13, 57-69. [CrossRef]

36. Hailey, D.W.; Rambold, A.S.; Satpute-Krishnan, P.; Mitra, K.; Sougrat, R.; Kim, P.K.; Lippincott-Schwartz, J. Mitochondria supply membranes for autophagosome biogenesis during starvation. Cell 2010, 141, 656-667. [CrossRef]

37. Yao, Z.; Klionsky, D.J. An unconventional pathway for mitochondrial protein degradation. Autophagy 2016, 12, 1971-1972. [CrossRef]

38. Kimura, T.; Mandell, M.; Deretic, V. Precision autophagy directed by receptor regulators-emerging examples within the TRIM family. J. Cell Sci. 2016, 129, 881-891. [CrossRef]

39. Martinon, F.; Burns, K.; Tschopp, J. The inflammasome: A molecular platform triggering activation of inflammatory caspases and processing of proIL-beta. Mol. Cell 2002, 10, 417-426. [CrossRef]

40. Rathinam, V.A.; Vanaja, S.K.; Fitzgerald, K.A. Regulation of inflammasome signaling. Nat. Immunol. 2012, 13, 333-342. [CrossRef]

41. Strowig, T.; Henao-Mejia, J.; Elinav, E.; Flavell, R. Inflammasomes in health and disease. Nature 2012, 481, 278-286. [CrossRef] [PubMed]

42. Guo, H.; Callaway, J.B.; Ting, J.P. Inflammasomes: Mechanism of action, role in disease, and therapeutics. Nat. Med. 2015, 21, 677-687. [CrossRef] [PubMed]

43. Mangan, M.S.J.; Olhava, E.J.; Roush, W.R.; Seidel, H.M.; Glick, G.D.; Latz, E. Targeting the NLRP3 inflammasome in inflammatory diseases. Nat. Rev. Drug Discov. 2018, 17, 588-606. [CrossRef] [PubMed] 
44. Rathinam, V.A.K.; Chan, F.K. Inflammasome, Inflammation, and Tissue Homeostasis. Trends Mol. Med. 2018, 24, 304-318. [CrossRef] [PubMed]

45. Becker, C.; Watson, A.J.; Neurath, M.F. Complex roles of caspases in the pathogenesis of inflammatory bowel disease. Gastroenterology 2013, 144, 283-293. [CrossRef] [PubMed]

46. Opipari, A.; Franchi, L. Role of inflammasomes in intestinal inflammation and Crohn's disease. Inflamm. Bowel Dis. 2015, 21, 173-181. [CrossRef]

47. de Souza, H.S.; Fiocchi, C. Immunopathogenesis of IBD: Current state of the art. Nat. Rev. Gastroenterol. Hepatol. 2016, 13, 13-27. [CrossRef]

48. de Souza, H.S.P. Etiopathogenesis of inflammatory bowel disease: Today and tomorrow. Curr. Opin. Gastroenterol. 2017, 33, 222-229. [CrossRef]

49. Lazaridis, L.D.; Pistiki, A.; Giamarellos-Bourboulis, E.J.; Georgitsi, M.; Damoraki, G.; Polymeros, D.; Dimitriadis, G.D.; Triantafyllou, K. Activation of NLRP3 inflammasome in inflammatory bowel disease: Differences between Crohn's disease and ulcerative colitis. Dig. Dis. Sci. 2017, 62, 2348-2356. [CrossRef]

50. Mao, L.; Kitani, A.; Similuk, M.; Oler, A.J.; Albenberg, L.; Kelsen, J.; Aktay, A.; Quezado, M.; Yao, M.; Montgomery-Recht, K.; et al. Loss-of-function CARD8 mutation causes NLRP3 inflammasome activation and Crohn's disease. J. Clin. Investig. 2018, 128, 1793-1806. [CrossRef]

51. Kawai, T.; Akira, S. The roles of TLRs, RLRs and NLRs in pathogen recognition. Int. Immunol. 2009, 21, 317-337. [CrossRef] [PubMed]

52. Giles, E.M.; Sanders, T.J.; McCarthy, N.E.; Lung, J.; Pathak, M.; MacDonald, T.T.; Lindsay, J.O.; Stagg, A.J. Regulation of human intestinal T-cell responses by type 1 interferon-STAT1 signaling is disrupted in inflammatory bowel disease. Mucosal Immunol. 2017, 10, 184-193. [CrossRef] [PubMed]

53. Saitoh, T.; Fujita, N.; Jang, M.H.; Uematsu, S.l.; Yang, B.G.; Satoh, T.; Omori, H.; Noda, T.; Yamamoto, N.; Komatsu, M.; et al. Loss of the autophagy protein Atg16L1 enhances endotoxin-induced IL-1beta production. Nature 2008, 456, 264-268. [CrossRef] [PubMed]

54. Zhou, R.; Yazdi, A.S.; Menu, P.; Tschopp, J. A role for mitochondria in NLRP3 inflammasome activation. Nature 2011, 469, 221-225. [CrossRef] [PubMed]

55. Wen, H.; Gris, D.; Lei, Y.; Jha, S.; Zhang, L.; Huang, M.T.; Brickey, W.J.; Ting, J.P. Fatty acid-induced NLRP3-ASC inflammasome activation interferes with insulin signaling. Nat. Immunol. 2011, 12, 408-415. [CrossRef] [PubMed]

56. Lupfer, C.; Thomas, P.G.; Anand, P.K.; Vogel, P.; Milasta, S.; Martinez, J.; Huang, G.; Green, M.; Kundu, M.; $\mathrm{Chi}, \mathrm{H}$;; et al. Receptor interacting protein kinase 2-mediated mitophagy regulates inflammasome activation during virus infection. Nat. Immunol. 2013, 14, 480-488. [CrossRef] [PubMed]

57. Chuang, S.Y.; Yang, C.H.; Chou, C.C.; Chiang, Y.P.; Chuang, T.H.; Hsu, L.C. TLR-induced PAI-2 expression suppresses IL-1 $\beta$ processing via increasing autophagy and NLRP3 degradation. Proc. Natl. Acad. Sci. USA 2013, 110, 16079-16084. [CrossRef]

58. Shi, C.S.; Shenderov, K.; Huang, N.N.; Kabat, J.; Abu-Asab, M.; Fitzgerald, K.A.; Sher, A.; Kehrl, J.H. Activation of autophagy by inflammatory signals limits IL- $1 \beta$ production by targeting ubiquitinated inflammasomes for destruction. Nat. Immunol. 2012, 13, 255-263. [CrossRef]

59. Harris, J.; Hartman, M.; Roche, C.; Zeng, S.G.; O'Shea, A.; Sharp, F.A.; Lambe, E.M.; Creagh, E.M.; Golenbock, D.T.; Tschopp, J.; et al. Autophagy controls IL-1beta secretion by targeting pro-IL-1beta for degradation. J. Biol. Chem. 2011, 286, 9587-9597. [CrossRef]

60. Deretic, V.; Kimura, T.; Timmins, G.; Moseley, P.; Chauhan, S.; Mandell, M. Immunologic manifestations of autophagy. J. Clin. Investig. 2015, 125, 75-84. [CrossRef]

61. Kimura, T.; Jain, A.; Choi, S.W.; Mandell, M.A.; Schroder, K.; Johansen, T.; Deretic, V. TRIM-mediated precision autophagy targets cytoplasmic regulators of innate immunity. J. Cell Biol. 2015, 210, 973-989. [CrossRef] [PubMed]

62. Dupont, N.; Jiang, S.; Pilli, M.; Ornatowski, W.; Bhattacharya, D.; Deretic, V. Autophagy-based unconventional secretory pathway for extracellular delivery of IL-1 $\beta$. EMBO J. 2011, 30, 4701-4711. [CrossRef] [PubMed]

63. Zhang, M.; Kenny, S.J.; Ge, L.; Xu, K.; Schekman, R. Translocation of interleukin-1 $\beta$ into a vesicle intermediate in autophagy-mediated secretion. Elife 2015, 4. [CrossRef]

64. Lee, H.K.; Lund, J.M.; Ramanathan, B.; Mizushima, N.; Iwasaki, A. Autophagy-dependent viral recognition by plasmacytoid dendritic cells. Science 2007, 315, 1398-1401. [CrossRef] [PubMed] 
65. Cooney, R.; Baker, J.; Brain, O.; Danis, B.; Pichulik, T.; Allan, P.; Ferguson, D.J.; Campbell, B.J.; Jewell, D.; Simmons, A. NOD2 stimulation induces autophagy in dendritic cells influencing bacterial handling and antigen presentation. Nat. Med. 2010, 16, 90-97. [CrossRef] [PubMed]

66. Homer, C.R.; Richmond, A.L.; Rebert, N.A.; Achkar, J.P.; McDonald, C. ATG16L1 and NOD2 interact in an autophagy-dependent antibacterial pathway implicated in Crohn's disease pathogenesis. Gastroenterology 2010, 139, 1630-1641. [CrossRef] [PubMed]

67. Travassos, L.H.; Carneiro, L.A.; Ramjeet, M.; Hussey, S.; Kim, Y.G.; Magalhães, J.G.; Yuan, L.; Soares, F.; Chea, E.; Le Bourhis, L.; et al. Nod1 and Nod2 direct autophagy by recruiting ATG16L1 to the plasma membrane at the site of bacterial entry. Nat. Immunol. 2010, 11, 55-62. [CrossRef]

68. Negroni, A.; Colantoni, E.; Vitali, R.; Palone, F.; Pierdomenico, M.; Costanzo, M.; Cesi, V.; Cucchiara, S.; Stronati, L. NOD2 induces autophagy to control AIEC bacteria infectiveness in intestinal epithelial cells. Inflamm. Res. 2016, 65, 803-813. [CrossRef]

69. Mizushima, N.; Noda, T.; Ohsumi, Y. Apg16p is required for the function of the Apg12p-Apg5p conjugate in the yeast autophagy pathway. EMBO J. 1999, 18, 3888-3896. [CrossRef] [PubMed]

70. Mizushima, N.; Kuma, A.; Kobayashi, Y.; Yamamoto, A.; Matsubae, M.; Takao, T.; Natsume, T.; Ohsumi, Y.; Yoshimori, T. Mouse Apg16L, a novel WD-repeat protein, targets to the autophagic isolation membrane with the Apg12-Apg5 conjugate. J. Cell Sci. 2003, 116, 1679-1688. [CrossRef]

71. Prescott, N.J.; Fisher, S.A.; Franke, A.; Hampe, J.; Onnie, C.M.; Soars, D.; Bagnall, R.; Mirza, M.M.; Sanderson, J.; Forbes, A.; et al. A nonsynonymous SNP in ATG16L1 predisposes to ileal Crohn's disease and is independent of CARD15 and IBD5. Gastroenterology 2007, 132, 1665-1671. [CrossRef] [PubMed]

72. Cadwell, K.; Liu, J.Y.; Brown, S.L.; Miyoshi, H.; Loh, J.; Lennerz, J.K.; Kishi, C.; Kc, W.; Carrero, J.A.; Hunt, S.; et al. A key role for autophagy and the autophagy gene Atg1611 in mouse and human intestinal Paneth cells. Nature 2008, 456, 259-263. [CrossRef] [PubMed]

73. Lassen, K.G.; Kuballa, P.; Conway, K.L.; Patel, K.K.; Becker, C.E.; Peloquin, J.M.; Villablanca, E.J.; Norman, J.M.; Liu, T.C.; Heath, R.J.; et al. Atg16L1 T300A variant decreases selective autophagy resulting in altered cytokine signaling and decreased antibacterial defense. Proc. Natl. Acad. Sci. USA 2014, 111, 7741-7746. [CrossRef] [PubMed]

74. Murthy, A.; Li, Y.; Peng, I.; Reichelt, M.; Katakam, A.K.; Noubade, R.; Roose-Girma, M.; DeVoss, J.; Diehl, L.; Graham, R.R.; et al. A Crohn's disease variant in Atg1611 enhances its degradation by caspase 3. Nature 2014, 506, 456-462. [CrossRef] [PubMed]

75. Chu, H.; Khosravi, A.; Kusumawardhani, I.P.; Kwon, A.H.; Vasconcelos, A.C.; Cunha, L.D.; Mayer, A.E.; Shen, Y.; Wu, W.L.; Kambal, A.; et al. Gene-microbiota interactions contribute to the pathogenesis of inflammatory bowel disease. Science 2016, 352, 1116-1120. [CrossRef] [PubMed]

76. Yue, C.; Yang, X.; Li, J.; Chen, X.; Zhao, X.; Chen, Y.; Wen, Y. Trimethylamine N-oxide prime NLRP3 inflammasome via inhibiting ATG16L1-induced autophagy in colonic epithelial cells. Biochem. Biophys. Res. Commun. 2017, 490, 541-551. [CrossRef] [PubMed]

77. Pott, J.; Kabat, A.M.; Maloy, K.J. Intestinal epithelial cell autophagy is required to protect against TNF-induced apoptosis during chronic colitis in mice. Cell Host Microbe 2018, 23, 191-202. [CrossRef] [PubMed]

78. Singh, S.B.; Davis, A.S.; Taylor, G.A.; Deretic, V. Human IRGM induces autophagy to eliminate intracellular mycobacteria. Science 2006, 313, 1438-1441. [CrossRef] [PubMed]

79. McCarroll, S.A.; Huett, A.; Kuballa, P.; Chilewski, S.D.; Landry, A.; Goyette, P.; Zody, M.C.; Hall, J.L.; Brant, S.R.; Cho, J.H.; et al. Deletion polymorphism upstream of IRGM associated with altered IRGM expression and Crohn's disease. Nat. Genet. 2008, 40, 1107-1112. [CrossRef]

80. Rufini, S.; Ciccacci, C.; Di Fusco, D.; Ruffa, A.; Pallone, F.; Novelli, G.; Biancone, L.; Borgiani, P. Autophagy and inflammatory bowel disease: Association between variants of the autophagy related IRGM gene and susceptibility to Crohn's disease. Dig. Liver Dis. 2015, 47, 744-750. [CrossRef]

81. Chauhan, S.; Mandell, M.A.; Deretic, V. IRGM governs the core autophagy machinery to conduct antimicrobial defense. Mol. Cell 2015, 58, 507-521. [CrossRef] [PubMed]

82. Crook, N.E.; Clem, R.J.; Miller, L.K. An apoptosis-inhibiting baculovirus gene with a zinc finger-like motif. J. Virol. 1993, 67, 2168-2174. [PubMed]

83. Eckelman, B.P.; Salvesen, G.S.; Scott, F.L. Human inhibitor of apoptosis proteins: Why XIAP is the black sheep of the family. EMBO Rep. 2006, 7, 988-994. [CrossRef] [PubMed] 
84. Mizushima, N.; Levine, B.; Cuervo, A.M.; Klionsky, D.J. Autophagy fights disease through cellular self-digestion. Nature 2008, 451, 1069-1075. [CrossRef] [PubMed]

85. Huang, X.; Wu, Z.; Mei, Y.; Wu, M. XIAP inhibits autophagy via XIAP-Mdm2-p53 signalling. EMBO J. 2013, 32, 2204-2216. [CrossRef] [PubMed]

86. Zeissig, Y.; Petersen, B.S.; Milutinovic, S.; Bosse, E.; Mayr, G.; Peuker, K.; Hartwig, J.; Keller, A.; Kohl, M.; Laass, M.W.; et al. XIAP variants in male Crohn's disease. Gut 2015, 64, 66-76. [CrossRef]

87. Schwerd, T.; Pandey, S.; Yang, H.T.; Bagola, K.; Jameson, E.; Jung, J.; Lachmann, R.H.; Shah, N.; Patel, S.Y.; Booth, C.; et al. Impaired antibacterial autophagy links granulomatous intestinal inflammation in Niemann-Pick disease type C1 and XIAP deficiency with NOD2 variants in Crohn's disease. Gut 2017, 66, 1060-1073. [CrossRef]

88. Elinav, E.; Strowig, T.; Henao-Mejia, J.; Flavell, R.A. Regulation of the antimicrobial response by NLR proteins. Immunity 2011, 34, 665-679. [CrossRef]

89. Yano, T.; Kurata, S. Intracellular recognition of pathogens and autophagy as an innate immune host defence. J. Biochem. 2011, 150, 143-149. [CrossRef]

90. Mazzini, E.; Massimiliano, L.; Penna, G.; Rescigno, M. Oral tolerance can be established via gap junction transfer of fed antigens from CX3CR1 ${ }^{+}$macrophages to $\mathrm{CD} 103^{+}$dendritic cells. Immunity 2014, 40, 248-261. [CrossRef]

91. Martin, B.; Hirota, K.; Cua, D.J.; Stockinger, B.; Veldhoen, M. Interleukin-17-producing gamma delta T cells selectively expand in response topathogen products and environmental signals. Immunity 2009, 31, 321-330. [CrossRef] [PubMed]

92. Talero, E.; Garcia-Maurino, S.; Motilva, V. Melatonin, autophagy and intestinal bowel disease. Curr. Pharm. Des. 2014, 20, 4816-4827. [CrossRef] [PubMed]

93. Münz, C. Autophagy beyond intracellular MHC class II antigen presentation. Trends. Immunol. 2016, 37, 755-763. [CrossRef] [PubMed]

94. Strisciuglio, C.; Duijvestein, M.; Verhaar, A.P.; Vos, A.C.; van den Brink, G.R.; Hommes, D.W.; Wildenberg, M.E. Impaired autophagy leads to abnormal dendritic cell-epithelial cell interactions. J. Crohns. Colitis. 2013, 7, 534-541. [CrossRef]

95. Lapaquette, P.; Bringer, M.A.; Darfeuille-Michaud, A. Defects in autophagy favour adherent-invasive Escherichia coli persistence within macrophages leading to increased pro-inflammatory response. Cell. Microbiol. 2012, 14, 791-807. [CrossRef] [PubMed]

96. Lassen, K.G.; McKenzie, C.I.; Mari, M.; Murano, T.; Begun, J.; Baxt, L.A.; Goel, G.; Villablanca, E.J.; Kuo, S.Y.; Huang, H.; et al. Genetic coding variant in GPR65 alters lysosomal pH and links lysosomal dysfunction with colitis risk. Immunity 2016, 44, 1392-1405. [CrossRef] [PubMed]

97. Meunier, E.; Dick, M.S.; Dreier, R.F.; Schürmann, N.; Kenzelmann Broz, D.; Warming, S.; Roose-Girma, M.; Bumann, D.; Kayagaki, N.; Takeda, K.; et al. Caspase-11 activation requires lysis of pathogen-containing vacuoles by IFN-induced GTPases. Nature 2014, 509, 366-370. [CrossRef]

98. Ke, P.; Shao, B.Z.; Xu, Z.Q.; Wei, W.; Han, B.Z.; Chen, X.W.; Su, D.F.; Liu, C. Activation of cannabinoid receptor 2 ameliorates DSS-induced colitis through inhibiting NLRP3 inflammasome in macrophages. PLoS ONE 2016, 11, e0155076. [CrossRef]

99. Samie, M.; Lim, J.; Verschueren, E.; Baughman, J.M.; Peng, I.; Wong, A.; Kwon, Y.; Senbabaoglu, Y.; Hackney, J.A.; Keir, M.; et al. Selective autophagy of the adaptor TRIF regulates innate inflammatory signaling. Nat. Immunol. 2018, 19, 246-254. [CrossRef]

100. Fan, K.; Lin, L.; Ai, Q.; Wan, J.; Dai, J.; Liu, G.; Tang, L.; Yang, Y.; Ge, P.; Jiang, R.; et al. Lipopolysaccharide-induced dephosphorylation of AMPK-activated protein kinase potentiates inflammatory injury via repression of ULK1-dependent autophagy. Front. Immunol. 2018, 9, 1464. [CrossRef]

101. Zhang, H.; Zheng, L.; Chen, J.; Fukata, M.; Ichikawa, R.; Shih, D.Q.; Zhang, X. The protection role of Atg1611 in CD11c+dendritic cells in murine colitis. Immunobiology 2017, 222, 831-841. [CrossRef] [PubMed]

102. Baxt, L.A.; Xavier, R.J. Role of autophagy in the maintenance of intestinal homeostasis. Gastroenterology 2015, 149, 553-562. [CrossRef] [PubMed]

103. Liu, E.; Van Grol, J.; Subauste, C.S. Atg5 but not Atg7 in dendritic cells enhances IL-2 and IFN- $\gamma$ production by Toxoplasma gondii-reactive CD4+ T cells. Microbes Infect. 2015, 17, 275-284. [CrossRef] [PubMed]

104. Kolaczkowska, E.; Kubes, P. Neutrophil recruitment and function in health and inflammation. Nat. Rev. Immunol. 2013, 13, 159-175. [CrossRef] [PubMed] 
105. Mantovani, A.; Cassatella, M.A.; Costantini, C.; Jaillon, S. Neutrophils in the activation and regulation of innate and adaptive immunity. Nat. Rev. Immunol. 2011, 11, 519-531. [CrossRef]

106. Wéra, O.; Lancellotti, P.; Oury, C. The dual role of neutrophils in inflammatory bowel diseases. Clin. Med. 2016, 5. [CrossRef]

107. Zhang, H.; Zheng, L.; McGovern, D.P.; Hamill, A.M.; Ichikawa, R.; Kanazawa, Y.; Luu, J.; Kumagai, K.; Cilluffo, M.; Fukata, M.; et al. Myeloid ATG16L1 facilitates host-bacteria interactions in maintaining intestinal homeostasis. J. Immunol. 2017, 198, 2133-2146. [CrossRef] [PubMed]

108. Chew, T.S.; O'Shea, N.R.; Sewell, G.W.; Oehlers, S.H.; Mulvey, C.M.; Crosier, P.S.; Godovac-Zimmermann, J.; Bloom, S.L.; Smith, A.M.; Segal, A.W. Optineurin deficiency in mice contributes to impaired cytokine secretion and neutrophil recruitment in bacteria-driven colitis. Dis. Model. Mech. 2015, 8, 817-829. [CrossRef] [PubMed]

109. Goldberg, R.; Prescott, N.; Lord, G.M.; MacDonald, T.T.; Powell, N. The unusual suspects-innate lymphoid cells as novel therapeutic targets in IBD. Nat. Rev. Gastroenterol. Hepatol. 2015, 12, 271-283. [CrossRef] [PubMed]

110. O'Sullivan, T.E.; Geary, C.D.; Weizman, O.E.; Geiger, T.L.; Rapp, M.; Dorn, G.W., 2nd; Overholtzer, M.; Sun, J.C. Atg5 is essential for the development and survival of innate lymphocytes. Cell Rep. 2016, 15, 1910-1919. [CrossRef]

111. Wang, S.; Xia, P.; Huang, G.; Zhu, P.; Liu, J.; Ye, B.; Du, Y.; Fan, Z. FoxO1-mediated autophagy is required for NK cell development and innate immunity. Nat. Commun. 2016, 7, 11023. [CrossRef] [PubMed]

112. López-Soto, A.; Bravo-San Pedro, J.M.; Kroemer, G.; Galluzzi, L.; Gonzalez, S. Involvement of autophagy in NK cell development and function. Autophagy 2017, 13, 633-636. [CrossRef] [PubMed]

113. Heller, F.; Fuss, I.J.; Nieuwenhuis, E.E.; Blumberg, R.S.; Strober, W. Oxazolone colitis, a Th2 colitis model resembling ulcerative colitis, is mediated by IL-13-producing NK-T cells. Immunity 2002, 17, 629-638. [CrossRef]

114. Fuss, I.J.; Heller, F.; Boirivant, M.; Leon, F.; Yoshida, M.; Fichtner-Feigl, S.; Yang, Z.; Exley, M.; Kitani, A.; Blumberg, R.S.; et al. Nonclassical CD1d-restricted NK T cells that produce IL-13 characterize an atypical Th2 response in ulcerative colitis. J. Clin. Investig. 2004, 113, 1490-1497. [CrossRef] [PubMed]

115. Salio, M.; Puleston, D.J.; Mathan, T.S.; Shepherd, D.; Stranks, A.J.; Adamopoulou, E.; Veerapen, N.; Besra, G.S.; Hollander, G.A.; Simon, A.K. Essential role for autophagy during invariant NKT cell development. Proc. Natl. Acad. Sci. USA 2014, 111, E5678-E5687. [CrossRef] [PubMed]

116. Pei, B.; Zhao, M.; Miller, B.C.; Véla, J.L.; Bruinsma, M.W.; Virgin, H.W.; Kronenberg, M. Invariant NKT cells require autophagy to coordinate proliferation and survival signals during differentiation. J. Immunol. 2015, 194, 5872-5884. [CrossRef]

117. Zhu, L.; Xie, X.; Zhang, L.; Wang, H.; Jie, Z.; Zhou, X.; Shi, J.; Zhao, S.; Zhang, B.; Cheng, X. TBK-binding protein 1 regulates IL-15-induced autophagy and NKT cell survival. Nat. Commun. 2018, 9, 2812. [CrossRef]

118. Ouellette, A.J.; Hsieh, M.M.; Nosek, M.T.; Cano-Gauci, D.F.; Huttner, K.M.; Buick, R.N.; Selsted, M.E. Mouse Paneth cell defensins: Primary structures and antibacterial activities of numerous cryptdin isoforms. Infect. Immun. 1994, 62, 5040-5047.

119. Ayabe, T.; Satchell, D.P.; Wilson, C.L.; Parks, W.C.; Selsted, M.E.; Ouellette, A.J. Secretion of microbicidal alpha-defensins by intestinal Paneth cells in response to bacteria. Nat. Immunol. 2000, 1, 113-118. [CrossRef]

120. Bar Shira, E.; Friedman, A. Innate immune functions of avian intestinal epithelial cells: Response to bacterial stimuli and localization of responding cells in the developing avian digestive tract. PLOS ONE 2018, 13, e0200393. [CrossRef]

121. Cobo, E.R.; Holani, R.; Moreau, F.; Nakamura, K.; Ayabe, T.; Mastroianni, J.R.; Ouellette, A.; Chadee, K. Entamoeba histolytica alters ileal Paneth cell functions in intact and Muc2 mucin deficiency. Infect. Immun. 2018. [CrossRef] [PubMed]

122. Bel, S.; Pendse, M.; Wang, Y.; Li, Y.; Ruhn, K.A.; Hassell, B.; Leal, T.; Winter, S.E.; Xavier, R.J.; Hooper, L.V. Paneth cells secrete lysozyme via secretory autophagy during bacterial infection of the intestine. Science 2017, 357, 1047-1052. [CrossRef]

123. Stappenbeck, T.S.; McGovern, D.P.B. Paneth cell alterations in the development and phenotype of Crohn's disease. Gastroenterology 2017, 152, 322-326. [CrossRef] [PubMed] 
124. Urano, F.; Wang, X.; Bertolotti, A.; Zhang, Y.; Chung, P.; Harding, H.P.; Ron, D. Coupling of stress in the ER to activation of JNK protein kinases by transmembrane protein kinase IRE1. Science 2000, 287, 664-666. [CrossRef] [PubMed]

125. Oyadomari, S.; Mori, M. Roles of CHOP/GADD153 in endoplasmic reticulum stress. Cell Death Differ. 2004, 11, 381-389. [CrossRef] [PubMed]

126. Kaneko, M.; Niinuma, Y.; Nomura, Y. Activation signal of nuclear factor-kappa B in response to endoplasmic reticulum stress is transduced via IRE1 and tumor necrosis factor receptor-associated factor 2. Biol. Pharm. Bull. 2003, 26, 931-935. [CrossRef] [PubMed]

127. Fritz, T.; Niederreiter, L.; Adolph, T.; Blumberg, R.S.; Kaser, A. Crohn's disease: NOD2, autophagy and ER stress converge. Gut 2011, 60, 1580-1588. [CrossRef]

128. Kaser, A.; Blumberg, R.S. ATG16L1 Crohn's disease risk stresses the endoplasmic reticulum of Paneth cells. Gut 2014, 63, 1038-1039. [CrossRef] [PubMed]

129. Matsuzawa-Ishimoto, Y.; Shono, Y.; Gomez, L.E.; Hubbard-Lucey, V.M.; Cammer, M.; Neil, J.; Dewan, M.Z.; Lieberman, S.R.; Lazrak, A.; Marinis, J.M.; et al. Autophagy protein ATG16L1 prevents necroptosis in the intestinal epithelium. J. Exp. Med. 2017, 214, 3687-3705. [CrossRef]

130. Balmus, I.M.; Ciobica, A.; Trifan, A.; Stanciu, C. The implications of oxidative stress and antioxidant therapies in Inflammatory Bowel Disease: Clinical aspects and animal models. Saudi J. Gastroenterol. 2016, 22, 3-17. [CrossRef]

131. Chen, L.; You, Q.; Hu, L.; Gao, J.; Meng, Q.; Liu, W.; Wu, X.; Xu, Q. The antioxidant procyanidin reduces reactive oxygen species signaling in macrophages and ameliorates experimental colitis in mice. Front. Immunol. 2018, 8, 1910. [CrossRef] [PubMed]

132. Denson, L.A.; Jurickova, I.; Karns, R.; Shaw, K.A.; Cutler, D.J.; Okou, D.T.; Dodd, A.; Quinn, K.; Mondal, K.; Aronow, B.J.; et al. Clinical and genomic correlates of neutrophil reactive oxygen species production in pediatric patients with Crohn's disease. Gastroenterology 2018, 154, 2097-2110. [CrossRef] [PubMed]

133. Zhang, C.; Li, P.; Zhang, S.; Lei, R.; Li, B.; Wu, X.; Jiang, C.; Zhang, X.; Ma, R.; Yang, L.; et al. Oxidative stress-elicited autophagosome accumulation contributes to human neuroblastoma SH-SY5Y cell death induced by PBDE-47. Environ. Toxicol. Pharmacol. 2017, 56, 322-328. [CrossRef] [PubMed]

134. Cheung, E.C.; Ludwig, R.L.; Vousden, K.H. Mitochondrial localization of TIGAR under hypoxia stimulates HK2 and lowers ROS and cell death. Proc. Natl. Acad. Sci. USA 2012, 109, 20491-20496. [CrossRef] [PubMed]

135. Mahalingaiah, P.K.; Singh, K.P. Chronic oxidative stress increases growth and tumorigenic potential of MCF-7 breast cancer cells. PLoS ONE 2014, 9, e87371. [CrossRef] [PubMed]

136. Tal, M.C.; Sasai, M.; Lee, H.K.; Yordy, B.; Shadel, G.S.; Iwasaki, A. Absence of autophagy results in reactive oxygen species-dependent amplification of RLR signaling. Proc. Natl. Acad. Sci. USA 2009, 106, 770-775. [CrossRef]

137. Adolph, T.E.; Mayr, L.; Grabherr, F.; Tilg, H. Paneth cells and their antimicrobials in intestinal immunity. Curr. Pharm. Des. 2018, 24, 1121-1129. [CrossRef]

138. Kostic, A.D.; Xavier, R.J.; Gevers, D. The microbiome in inflammatory bowel disease: Current status and the future ahead. Gastroenterology 2014, 146, 1489-1499. [CrossRef]

139. Sun, J. VDR/vitamin D receptor regulates autophagic activity through ATG16L1. Autophagy 2016, 12, 1057-1058. [CrossRef]

140. Burger, E.; Araujo, A.; López-Yglesias, A.; Rajala, M.W.; Geng, L.; Levine, B.; Hooper, L.V.; Burstein, E.; Yarovinsky, F; ; et al. Loss of Paneth cell autophagy causes acute susceptibility to Toxoplasma gondii-mediated Inflammation. Cell Host Microbe 2018, 23, 177-190. [CrossRef]

141. Garrett, W.S.; Gordon, J.I.; Glimcher, L.H. Homeostasis and inflammation in the intestine. Cell 2010, 140, 859-870. [CrossRef] [PubMed]

142. Kim, D.H.; Kim, S.; Lee, J.H.; Kim, J.H.; Che, X.; Ma, H.W.; Seo, D.H.; Kim, T.I.; Kim, W.H.; Kim, S.W.; et al. Lactobacillus acidophilus suppresses intestinal inflammation by inhibiting endoplasmic reticulum stress. J. Gastroenterol. Hepatol. 2018. [CrossRef] [PubMed]

143. Ganji-Arjenaki, M.; Rafieian-Kopaei, M. Probiotics are a good choice in remission of inflammatory bowel diseases: A meta analysis and systematic review. J. Cell. Physiol. 2018, 233, 2091-2103. [CrossRef] [PubMed]

144. Verdugo, P. Goblet cells secretion and mucogenesis. Annu. Rev. Physiol. 1990, 52, 157-176. [CrossRef] [PubMed] 
145. Specian, R.D.; Oliver, M.G. Functional biology of intestinal goblet cells. Am. J. Physiol. 1991, 260, C183-C193. [CrossRef] [PubMed]

146. Itoh, H.; Beck, P.L.; Inoue, N.; Xavier, R.; Podolsky, D.K. A paradoxical reduction in susceptibility to colonic injury upon targeted transgenic ablation of goblet cells. J. Clin. Investig. 1999, 104, 1539-1547. [CrossRef] [PubMed]

147. Swidsinski, A.; Loening-Baucke, V.; Herber, A. Mucosal flora in Crohn's disease and ulcerative colitis-An overview. J. Physiol. Pharmacol. 2009, 60, 61-71. [PubMed]

148. Patel, K.K.; Miyoshi, H.; Beatty, W.L.; Head, R.D.; Malvin, N.P.; Cadwell, K.; Guan, J.L.; Saitoh, T.; Akira, S.; Seglen, P.O.; et al. Autophagy proteins control goblet cell function by potentiating reactive oxygen species production. EMBO J. 2013, 32, 3130-3144. [CrossRef]

149. Johansson, M.E.; Hansson, G.C. Is the intestinal goblet cell a major immune cell? Cell Host Microbe 2014, 15, 251-252. [CrossRef] [PubMed]

150. Wlodarska, M.; Thaiss, C.A.; Nowarski, R.; Henao-Mejia, J.; Zhang, J.P.; Brown, E.M.; Frankel, G.; Levy, M.; Katz, M.N.; Philbrick, W.M.; et al. NLRP6 inflammasome orchestrates the colonic host-microbial interface by regulating goblet cell mucus secretion. Cell 2014, 156, 1045-1059. [CrossRef] [PubMed]

151. Gagné-Sansfaçon, J.; Allaire, J.M.; Jones, C.; Boudreau, F.; Perreault, N. Loss of Sonic hedgehog leads to alterations in intestinal secretory cell maturation and autophagy. PLoS ONE 2014, 9, e98751. [CrossRef] [PubMed]

152. Wang, S.; Li, Q.; Zang, Y.; Zhao, Y.; Liu, N.; Wang, Y.; Xu, X.; Liu, L.; Mei, Q. Apple Polysaccharide inhibits microbial dysbiosis and chronic inflammation and modulates gut permeability in HFD-fed rats. Int. J. Biol. Macromol. 2017, 99, 282-292. [CrossRef] [PubMed]

153. El-Khider, F.; McDonald, C. Links of Autophagy Dysfunction to Inflammatory Bowel Disease Onset. Dig. Dis. 2016, 34, 27-34. [CrossRef] [PubMed]

154. Ke, P.; Shao, B.Z.; Xu, Z.Q.; Chen, X.W.; Liu, C. Intestinal Autophagy and Its Pharmacological Control in Inflammatory Bowel Disease. Front. Immunol. 2017, 7, 695. [CrossRef] [PubMed]

(C) 2018 by the authors. Licensee MDPI, Basel, Switzerland. This article is an open access article distributed under the terms and conditions of the Creative Commons Attribution (CC BY) license (http:/ / creativecommons.org/licenses/by/4.0/). 